RESEARCH ARTICLE

\title{
ROOT SYSTEM ATTRIBUTES, MORPHOLOGY AND YIELD OF COWPEA (Vigna unguiculata L. Walp.) UNDER MOISTURE STRESS
}

\author{
Harshani HKA and Fernando KMC* \\ Department of Crop Science, Faculty of Agriculture, University of Ruhuna, Mapalana, \\ Kamburupitiya, Sri Lanka
}

Received: 2021.05.13, Accepted: 2021.07.31

\begin{abstract}
Cowpea is an important grain legume crop and inexpensive plant protein source cultivated year around in Sri Lanka. Tolerance to moisture stress is a critical factor for getting high production of cowpea growing in the Dry

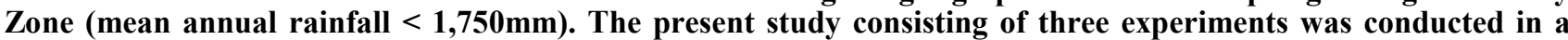
protected house and laboratory conditions to determine the relationship of root traits with plant morphology and yield among eight cowpea varieties grown in Sri Lanka under moisture stress conditions. The eight cowpea varieties and two moisture stress levels were used as experimental factors and set up as a two-factor factorial completely randomized design. The interaction effect between the two factors were not significant for morphological traits such as the number of branches, plant height, number of leaves and basal stem diameter, but some of those traits significantly influenced by the main factors. The yield and root attributes such as the pod length, 100 seed dry weight and root dry weight at maturity were significantly influenced by the interaction while the number of flowers per plant, the number of pods per plant, the number of seeds per pod and the aboveground biomass per plant were not significantly affected by the interaction. However, those parameters varied significantly with variety and moisture stress levels. Furthermore, the interaction effect was significant for the water use efficiency of the mature plants. The basal root growth angle, taproot diameter at $5 \mathrm{~cm}$ level and length of the taproot at maturity were significantly affected by the interaction. Additionally, seedlings grown in cotton wool culture reported a significant interaction effect of main factors on the length of the taproot, the total root length and root dry weight except for the number of lateral roots. However, the Interaction effect of variety and moisture stress was significant for the majority of root attributes such as length of the taproot, total root length and the number of lateral roots of the seedlings grown in sand media. A positive correlation found between the total root length of the mature plant and the above-ground biomass. All seedling root traits measured in cotton wool culture showed a negative correlation with the above-ground biomass of mature plants while none of the seedling root traits in sand media had an association with above-ground biomass. All root traits recorded in mature plants showed a significant negative and positive correlation with important yield attributes of cowpea. Therefore, identified favourable root attributes related to morphology and yield components of cowpea could be used as screening parameters of cowpea populations at the seedling stage to identify efficient genotypes under moisture stress levels and introduce them to breeding programs.
\end{abstract}

Keywords: Cowpea, Moisture stress, Morphology, Root traits, Varieties, Yield traits

\section{INTRODUCTION}

Drought stress is identified as one of the abiotic not non-biotic factors that limit crop production globally. It badly affects crop growth, development and economic yield (Farooq et al. 2009). Irregular precipitation due to changing climate would further enhance the drought stress (Lesk et al. 2016). It is estimated that due to climate change-related

*Corresponding author: menaka@crop.ruh.ac.lk scenarios, $30-82 \%$ of the crop yield could be reduced by the end of the $21^{\text {st }}$ century (Hatfield et al. 2011). Since water deficit is one of the main abiotic not non-biotic factors that negatively affect global food production (Agbicodo et al. 2009; Cruz de Carvalho 2008), the concern of scientists on the impact of drought-induced by climate-changing scenarios on crop growth and yield increased drastically (Carvalho et al. 2019). Cowpea is a grain legume crop that belongs to the family 
Fabaceae. At present, it is mainly cultivated in tropical and sub-tropical areas despite of its origin in the African continent(Timko et al. 2007). Cowpea is well-recognized as a crop component that contributes massively to food security and income generation of resources poor farmers (Carlos 2000). On the other hand, biological nitrogen fixation improves soil fertility in sustainable production systems (Martins et al. 2003). Cowpea adapts to the dry and hot regions of the tropics and subtropics due to its drought-tolerant properties (Merwad et al. 2018). However, yield losses of cowpea are possible due to severe drought in their major growing environments. Therefore, cowpea varieties resistant to water-limited environments and tolerant to heat stress while increasing biological nitrogen fixation efficiency were developed by researchers and plant breeders (Singh, 2014). Significant heterogeneity is available between cowpea genotypes for morphological, physiological and yield characteristics with and without drought stress (Mwale et al. 2017).

Cowpea is one of the major grain legume crops cultivated in Hambanthota, Rathnapura, Badulla, Monaragala, Anuradhapura, Kurunegala, Batticaloa, Mahaweli System 'H', Ampara and Polonnaruwa districts in Sri Lanka. It plays a major role in the cropping systems and farming systems in dry and intermediate regions of the country (Abearathne et al., 2013). Cowpea is cultivated in 7,196 ha with a total and annual average yield of 8,067 t and $1.12 \mathrm{t} \mathrm{ha}^{-1}$ in 2019 (AgStat, 2020). Cowpea production in Sri Lanka varies from year to year. According to Alidu (2018), drought severity and timing in relation to the crop's life cycle, as well as high night temperatures, are significant constraints on long-term cowpea production.

Less attention has been given to the genotypic and phenotypic variations of root architectural traits on crop growth and yield performances in cowpea (Burridge et al. 2016). Cowpea has epigeal germination and an embryonic root system which comprises primary root and basal roots (Lynch and Beem, 1993). The primary root developed into taproot and many lateral roots emerge from the taproot. Access to soil water and nitrogen of the plant is determined by root system architecture (Lynch, 2013). However, less consideration is given to the root morphological features and their relationships with economic yield and morphological characters under soil moisture stress conditions of cowpea. Therefore, the aim of this study was to find out the relationship between seedling root traits and the final yield and morphological characters of cowpea in response to soil moisture stress.

\section{MATERIALS AND METHODS Experimental site}

The present study was carried out at the Department of Crop Science, Faculty of Agriculture, University of Ruhuna from December 2020 to March 2021 . Plants were grown in the protected house with light intensity of 25,000 lux and day-night temperatures of 40 and $28^{\circ} \mathrm{C}$, respectively.

\section{Experiments designs and treatments}

The first experiment was conducted under natural daylight conditions (LD 12: 12) of the protected house conditions using polythene bag containers $(20 \times 25 \mathrm{~cm})$. This was done to evaluate the morphology, yield and root traits of cowpea varieties at maturity. It was established as a two factor factorial completely randomized block design with three replicates to account for the variation of photosynthetically active radiation in the protected house. Eight cowpea varieties (Dawala, Waruni, Wijaya, Bombay, MI35, MICP1, ANKCP1, ANKCP2) available in Sri Lanka and two moisture stress levels (MS) $(\mathrm{MS} 1=30 \%$ of the Pot Soil Water Capacity (PSWC), MS2 $=50 \%$ of the PSWC) were used as treatments. The potting mixture was prepared using topsoil: sand: compost into a 2: 1: 1 ratio. The bulk density of the mixture was $1.17 \mathrm{gcm}^{-3}$.

Basal and top dressings were done according to the recommendations of the Department of Agriculture (DOA) Sri Lanka. The basal dressing was applied for the potting media, one day before the seed sowing while top dressing was done at the beginning of flowering. Before seed sowing, the germination percentage of the seeds was 
calculated and a seed viability test was done. Then seeds were soaked in water for 24 hours and kept another 24 hours to synchronize the germination. After that, synchronized seeds were placed in the polythene bags as two seeds per bag, randomly within the block. After two weeks of seed sowing, one seedling was removed from the bag by leaving a single healthy and vigorous plant per polythene bag. Irrigation was practiced immediately after seed sowing up to two weeks as needed before induced the moisture stress. Moisture stress was implemented based on the PSWC of the potting media. The field capacity of the potting media was determined as follows; potting media of one polythene bag was ovendried at $105^{\circ} \mathrm{C}$ for 24 hours to get constant mass. Then, it was saturated with water until the water drained freely from the bottom of the bag and kept 72 hours to get into the field capacity. The amount of water supply to induce moisture stress was calculated based on the amount of water in the pot soil sample at field capacity. The same procedure was done for ten replicates and the value was taken as the field capacity. The PSWC of the mixture in the polythene bag was $200 \mathrm{ml}$.

Pinching was practiced 18 days after seed sowing to form the bushy type plant and get more productive branches. All other agronomic practices were done according to the recommendation of the DOA. Cowpea pods were harvested selectively when they reached the physiological maturity. Harvesting began approximately 45-50 days after seed sowing depending on the variety. Seeds were manually removed from pods and sun-dried before being taking the dry weight.

The second experiment was conducted to study the root morphological characteristics of seedlings growing in cotton wool under laboratory conditions using two factor factorial completely randomized designs. The same genetic materials were used as in experiment one. In this experiment, one hundred and sixty Petri dishes were washed, and the Petri dishes were laid out with cotton wool. As in experiment one, water was sprayed to damp the cotton wool according to the two moisture levels. After that, the wet tissue paper was laid on wet cotton wool and overnight soaked seeds were placed on wet tissue paper. All these Petri dishes were eventually covered in black polythene. At the begining, the volume of water needs to damp the cotton wool layer was recorded by adding water gradually to ten Petri dishes and took the average $(12 \mathrm{ml})$. Two moisture stress levels were imposed by adding 30\% (MS1, $4 \mathrm{ml}$ ) and $50 \%(\mathrm{MS} 2,6 \mathrm{ml})$ of the volume of water required to damp the cotton wool in the Petri dish.

The third experiment was a lab experiment that was conducted to examine the seedling root traits of cowpea in sand media under two moisture stress levels. The same genetic materials were used as in the previous experiments. This experiment was arranged with sixteen treatments and five replicates in a two-factor factorial completely randomized design. For the experiment, the glass boxes $(20 \mathrm{~cm} \times 20 \mathrm{~cm} \times 1 \mathrm{~cm})$ filled with washedfine sand was used as media. Overnight soaked seeds were placed near the edge of the box in sand media. Ten glass- boxes were filled with oven-dried washed-fine sand and applied water gradually to record the moisture requirement to make sands moist $(212 \mathrm{ml})$. After that, two moisture stress levels induced by adding $30 \%(\mathrm{MS} 1,65 \mathrm{ml})$ and $50 \%(\mathrm{MS} 2$, $106 \mathrm{ml}$ ) of the volume of water required to wet the sand inside the glad box.

\section{Measurements}

Morphological traits were recorded from three weeks after seed sowing to harvesting in the first experiment. Number of leaves per plant, plant height (as the height of the main stem), number of flowers per plant, number of branches per plant, above-ground biomass and basal diameter of the stem were recorded as morphological traits. The number of pods per plant, pod length, number of seeds per pod and weight of the 100 seeds were taken as yield traits.

Root traits were evaluated by uprooting the plants at maturity. Root dry weight, basal root growth angles, taproot diameter (at $5 \mathrm{~cm}$ below the soil surface) (Burridge et al., 2016) and taproot length were recorded. Thoroughly 
washed roots were placed in labelled paper bags and oven-dried for 72 hours at $65^{\circ} \mathrm{C}$ until the weight was constant to get the dryweight. Basal root growth angle was also measured after uprooting the plants. The approximate angle where basal roots intersect $10 \mathrm{~cm}$ arc on board (zero is horizontal and $90^{\circ}$ is vertical) when root origin placed in centre was measured (Burridge et al., 2016). Then basal root growth angle of each treatment was taken from three replicates.

The second leaf of the main stem of each plant was used to calculate the leaf relative water content (LRWC). The leaves were wrapped in aluminium foil immediately after cutting at the base of the lamina, sealed inside a plastic bag, and placed in a cooler. Fresh weight after excision was determined within 2 hours. After soaking, the leaves for 16 to 18 hours in distilled water at room temperature (about $30^{\circ} \mathrm{C}$ ), turgid weight was obtained. Leaves were quickly and carefully blotted with tissue paper after soaking before the turgid weight was determined. After ovendrying the leaf samples for 72 hours at $70^{\circ} \mathrm{C}$, the dry weight was obtained. The LRWC was calculated from equation 1 (Schonfeld et al., 1988).

$$
\text { LRWC }(\%)=\frac{F W-D W}{\mathrm{TW}-\mathrm{DW}} \times 100 \ldots \text { eqn } 1
$$

Where, $F W=$ Fresh weight, DW=Dry weight, $T W=$ Turgid weight

The agricultural water use efficiency (WUE) of the varieties under different soil moisture stresses was calculated at the end of the experiment. Tejero et al. (2011) defined agricultural WUE as the ratio between economic yield and volume of the water applied to the crop throughout the life cycle (equation 2).

$$
\text { WUE }\left(\frac{\mathrm{kg}}{\mathrm{m}^{3}}\right)=\frac{\text { Yield (economic) }}{\text { Irrigation }} \ldots \text { eqn } 2
$$

Data were collected after seven days of seed sowing of the second and third experiments. Length of the taproot, total root length, number of lateral roots per seedling and seedling root dry weight were taken as root morphological traits of the seedlings in the second experiment. Same traits except seedling dry weight were recorded in the third experiment.

\section{Data analysis}

The data were analyzed using statistical software of SAS and Minitab 17. ANOVA appropriate to the experiment design was performed to separate means. The Duncan Multiple Range Test at the probability of 5\% was used to compare means of single factors and LSD was used to identify the difference between mean values of the interaction effects of the main factors. Pearson correlation analysis was implemented to identify the relationship between variables. Descriptive data were presented using graphs in MS Excel.

\section{RESULTS AND DISCUSSION}

According to the results of the first experiment, the number of branches per plant was not significantly affected by the interaction between two main factors ( $\mathrm{V} x$ MS) or individual factors of variety and moisture stresses level (Table 1). According to Yahaya et al. (2019), the number of branches per plant was unaffected by the watering level. However, Ndimbo et al. (2015) found that common bean branching was reduced by the low volume of water treatment, while a high volume of water treatment recorded greater branching ability which in contrast with the findings of the present experiment. Similarly, there was no significant interaction between $\mathrm{V} \times \mathrm{MS}$ and moisture stress on the plant height. However, it was significantly different among the varieties $(\mathrm{P}<0.001$; Table 1$)$. The tallest plant was observed in var. Bombay but plant height was not significantly different from var. Waruni and var. Wijaya. Var. MI35 recorded the shortest plants, but it was not significantly different from var. Dawala and var. MICP1. Ndimbo et al. (2015) confirmed that the plant height of the common bean decreased when increasing the amount of water provided for its growth. 
The number of leaves per plant was not significantly different among V x MS and the main effect of moisture stress level but depend on the main effect of variety $(\mathrm{P}<0.01$; Table 1). The highest number of leaves per plant was recorded in var. MI35, but it was not significantly different from var. Dawala, var. wijaya, var. MICP1 and var. ANKCP1. Bombay variety recorded the significantly lowest number of leaves per plant, but it was not significantly different among var. Dawala, var. Waruni, var. ANKCP1 and var. ANKCP2. However, according to Yahaya et al. (2019) the number of leaves per plant was highly sensitive to drought stress. The basal diameter of the stem was not significantly affected by $\mathrm{V} \times \mathrm{MS}$. However, the varietal effect $(\mathrm{P}<0.001)$ and moisture stress level $(\mathrm{P}<0.001)$ were significant for the basal diameter of the stem.

The number of flowers per plant, the number of pods per plant, the number of seeds per pod and above-ground biomass per plant were not significantly affected by $\mathrm{V} \times \mathrm{MS}$. However, all the above-mentioned parameters varied significantly with varieties and moisture stress. The highest number of flowers was recorded in var. Dawala (Fig. 1A). Though, it was not significantly different from var. Waruni, var. Wijaya, var. MICP1 and var.ANKCP1. However, var. ANKCP2 recorded the lowest number of flowers per plant and did not significantly different from var. Bombay and var. MI35. The highest number of flowers per plant was recorded under a lower soil moisture stress level (Fig. 1B). According to Abayomi and Abidoye (2009), the higher soil moisture stress levels significantly reduced the number of flowers per plant, although they significantly delayed the onset of flowering and the date to full flowering. In the present experiment, the highest number of pods per plant was recorded in var. Waruni and was significantly different from all other varieties (Fig. 1C).Var. Bombay recorded the lowest average number of pods per plant, but it was not significantly different from other varieties except var. waruni. However, the highest average number of pods per plant was recorded under a lower moisture stress level (Fig. 1D). A similar result was obtained by Abayomi and Abidoy (2009) where the

Table 1: Number of branches, plant height, number of leaves and basal diameter of the stem with standard error of the means for eight cowpea varieties under two moisture stress levels in experiment one.

\begin{tabular}{lllll}
\hline Treatments & $\begin{array}{l}\text { Number of } \\
\text { branches }\end{array}$ & $\begin{array}{l}\text { Plant height } \\
(\mathbf{c m})\end{array}$ & $\begin{array}{l}\text { Number of } \\
\text { leaves }\end{array}$ & $\begin{array}{l}\text { Basal diameter } \\
\text { of stem (cm) }\end{array}$ \\
\hline Dawala & $1.50^{\mathrm{a}} \pm 0.22$ & $18.83^{\mathrm{de}} \pm 0.71$ & $4.66^{\mathrm{ab}} \pm 0.49$ & $0.59^{\mathrm{b}} \pm 0.04$ \\
Waruni & $1.60^{\mathrm{a}} \pm 0.22$ & $24.00^{\mathrm{ab}} \pm 1.46$ & $4.00^{\mathrm{b}} \pm 0.25$ & $0.65^{\mathrm{b}} \pm 0.03$ \\
Wijaya & $1.66^{\mathrm{a}} \pm 0.21$ & $24.75^{\mathrm{ab}} \pm 0.88$ & $5.16^{\mathrm{a}} \pm 0.47$ & $0.73^{\mathrm{a}} \pm 0.04$ \\
Bombay & $1.33^{\mathrm{a}} \pm 0.21$ & $26.33^{\mathrm{a}} \pm 0.92$ & $3.66^{\mathrm{b}} \pm 0.33$ & $0.75^{\mathrm{a}} \pm 0.05$ \\
MI35 & $1.33^{\mathrm{a}} \pm 0.21$ & $17.83^{\mathrm{e}} \pm 1.02$ & $5.33^{\mathrm{a}} \pm 0.33$ & $0.25^{\mathrm{b}} \pm 0.04$ \\
MICP1 & $1.33^{\mathrm{a}} \pm 0.21$ & $19.91^{\mathrm{cde}} \pm 1.15$ & $5.16^{\mathrm{a}} \pm 0.54$ & $0.60^{\mathrm{b}} \pm 0.03$ \\
ANKCP1 & $1.83^{\mathrm{a}} \pm 0.16$ & $22.50^{\mathrm{bc}} \pm 1.03$ & $4.66^{\mathrm{ab}} \pm 0.21$ & $0.56^{\mathrm{b}} \pm 0.03$ \\
ANKCP2 & $1.66^{\mathrm{a}} \pm 0.21$ & $21.91^{\mathrm{bcd}} \pm 1.06$ & $3.83^{\mathrm{b}} \pm 0.16$ & $0.65^{\mathrm{b}} \pm 0.04$ \\
\hline P value (V) & 0.451 & $<0.001$ & $<0.01$ & $<0.001$ \\
\hline MS1 & $1.56^{\mathrm{a}} \pm 0.10$ & $21.41^{\mathrm{b}} \pm 0.78$ & $4.45^{\mathrm{b}} \pm 0.21$ & $0.57^{\mathrm{b}} \pm 0.01$ \\
MS2 & $1.50^{\mathrm{a}} \pm 0.10$ & $22.47^{\mathrm{a}} \pm 0.75$ & $4.66^{\mathrm{a}} \pm 0.21$ & $0.71^{\mathrm{a}} \pm 0.02$ \\
\hline P value (MS) & 0.633 & 0.170 & 0.404 & $<0.001$ \\
\hline CV\% & 13.271 & 11.960 & 18.715 & 10.451 \\
\hline
\end{tabular}

Remarks: $V=$ variety, $M S=$ moisture stress, $C V=$ coefficient of variation. Mean values followed by the same letters are not significantly different at $P<0.05$ 

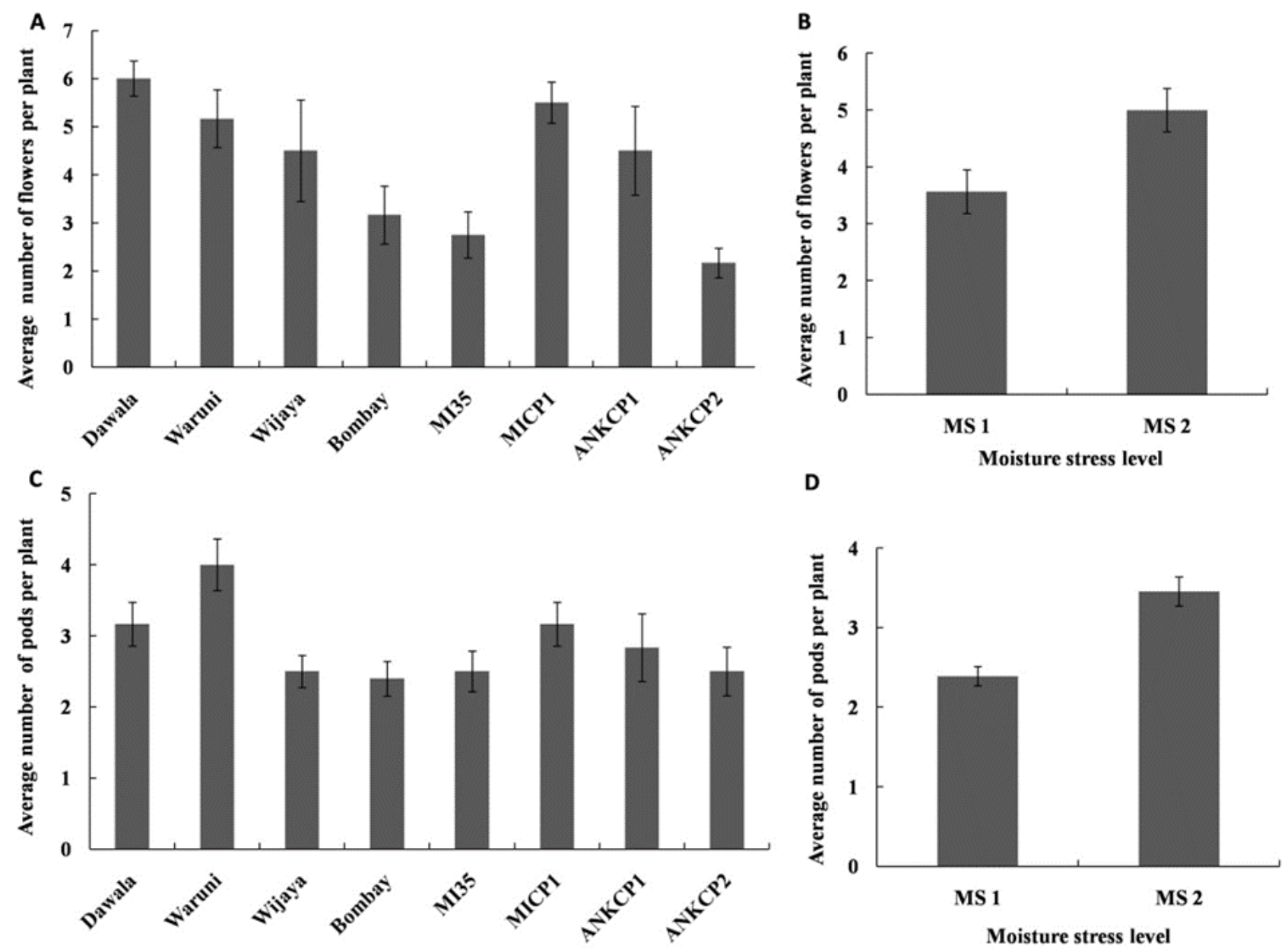

Figure 1: (A) Effect of variety on the number of flowers per plant $(\mathrm{P}<0.001)(B)$ moisture stress level on the number of flowers per $\operatorname{plant}(\mathrm{P}<0.001)(\mathrm{C})$ varietal effect on the number of pods per plant $(\mathrm{P}<0.001)$ and (D) moisture stress level on the number of pods per plant $(\mathbf{P}<\mathbf{0 . 0 0 1})$.Moisture stress; MS1- 30\% of the Pot Soil Water Capacity and MS2- 50\% of the Pot Soil Water Capacity is supplied when reached to the temporary wilting point. The standard error of the mean is indicated by error bars.

number of pods per plant was significantly reduced when soil moisture stress was increased. The highest number of seeds per pod was recorded in var. MI35 and was significantly different from all other varieties (Fig. 2A). Var. Dawala recorded the lowest number of seeds per pod, but it was not significantly different from all other varieties except var. MI35. Furthermore, the highest number of seeds per pod was recorded under a lower moisture stress level (Fig. 2B). According to Ndimbo et al. (2015), the crop yield of common bean is influenced by moisture level and intense moisture stress decreases the yields significantly. Variety $(\mathrm{P}<0.05)$ and the moisture stress level
$(\mathrm{P}<0.05)$ affected the above-ground biomass production per plant of cowpea. According to Fig. 2C, the greatest above-ground biomass per plant was recorded in var. ANKCP2 and was significantly higher than all other varieties while the lowest value was reported by var. Dawala. The highest above-ground biomass production was observed under less moisture stress level (Fig. 2D).

The pod length and 100 seeds dry weight were significantly affected by the interaction of variety and moisture stress level $(\mathrm{P}<0.05$; Table 2). Abayomi and Abidoye (2009) found that the high soil moisture stress resulted in a significant reduction in the number of pods 

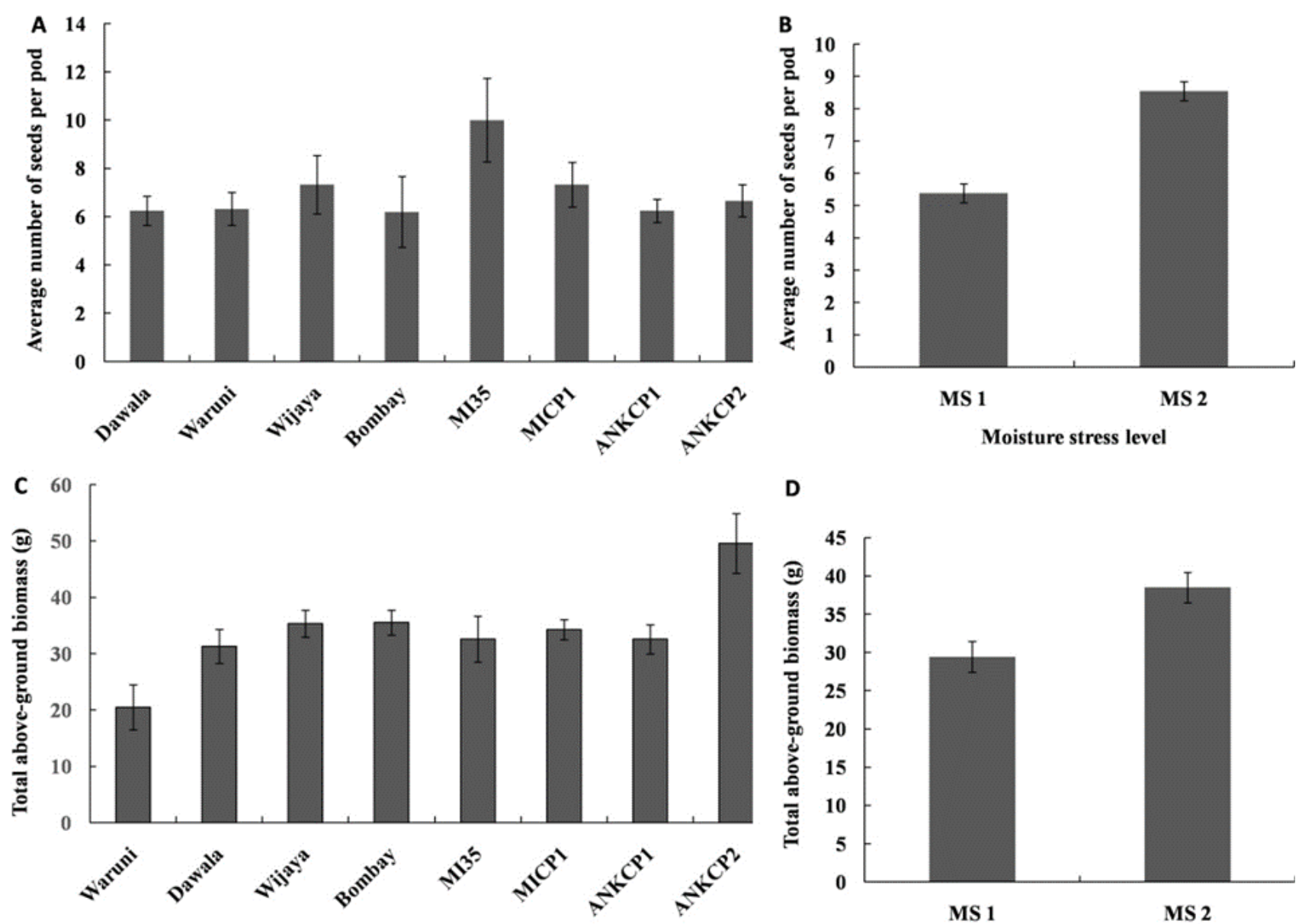

D

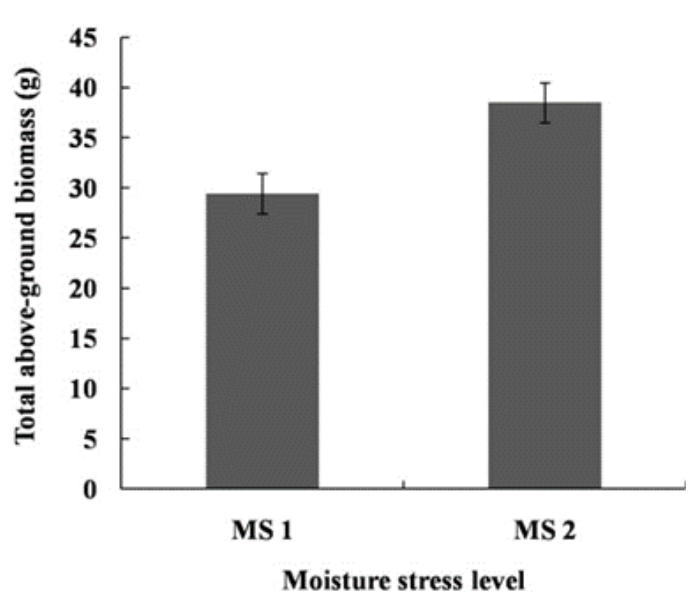

Figure 2: (A) Effect of variety on the number of seeds per plant $(\mathrm{P}<0.001)(\mathrm{B})$ moisture stress level on the number of seeds per plant $(\mathrm{P}<0.001)(\mathrm{C})$ varietal effect on above-ground biomass production per plant $(\mathrm{P}<\mathbf{0 . 0 0 1})$ and $(\mathrm{D})$ moisture stress level on above-ground biomass production per plant $(\mathrm{P}<0.001)$. Moisture stress level; MS1- 30\% of the Pot Soil Water Capacity and MS2- 50\% of the Pot Soil Water Capacity is supplied when reached to the temporary wilting point. The standard error of the mean is indicated by error bars.

per plant and the number of seeds per plant. Therefore, the ultimate result is a significant reduction in grain production or economic yield.

The effect of $\mathrm{V} x$ MS was not significant for the relative water content of the leaf. It was only affected by the moisture stress level of the present study $(\mathrm{P}<0.05)$. The relative water content of the leaf was greater $(87 \%)$ in less moisture stress plants than high moisture stressed plants (84\%). However, V x MS was significant $(\mathrm{P}<0.001)$ for the water-use efficiency of the plant. Treatment 2 (var. Waruni under high moisture stress level) recorded the highest water-use efficiency among all other treatments. Therefore it can be suggested that var. Waruni could perform better under water-limited environments. In general, water use efficiency increased under the high moisture stress level in the present study (Figure 3 ).

\section{Root Parameters}

Root parameters of cowpea varieties under two moisture stress levels in three experiments were shown in tables 3, 4 and 5 . Root traits were evaluated in different growth stages of plants (maturity and seedling stages), while in different growth media for seedlings 
Table 2: Mean interaction effect of pod length and 100 seeds dry weight of eight cowpea varieties under two moisture stress

\begin{tabular}{lllr}
\hline $\begin{array}{l}\text { Soil } \\
\text { moisture } \\
\text { stress } \\
\text { level }\end{array}$ & Variety & $\begin{array}{l}\text { Pod } \\
\text { length } \\
\text { (cm) }\end{array}$ & $\begin{array}{r}\text { 100 } \\
\text { seeds } \\
\text { dry } \\
\text { weight } \\
\text { (g) }\end{array}$ \\
\hline & Dawala & 13.58 & 16.74 \\
& Waruni & 13.28 & 15.17 \\
& Wijaya & 15.75 & 10.92 \\
MS1 & Bombay & 11.88 & 22.71 \\
& MI35 & 12.63 & 11.63 \\
& MICP1 & 12.33 & 10.92 \\
& ANKCP1 & 11.25 & 21.30 \\
& ANKCP2 & 15.90 & 24.65 \\
\hline & Dawala & 09.75 & 12.92 \\
& Waruni & 11.83 & 12.24 \\
& Wijaya & 10.47 & 13.52 \\
MS2 & Bombay & 11.50 & 19.00 \\
& MI35 & 09.75 & 08.68 \\
& MICP1 & 10.17 & 09.43 \\
& ANKCP1 & 11.83 & 15.40 \\
& ANKCP2 & 10.58 & 14.03 \\
\hline \multirow{4}{*}{ P value } & V $\times$ MS & 1.741 & 2.468 \\
\hline & LSD] & & \\
\hline & & $<0.001$ & $<0.001$ \\
\hline
\end{tabular}

V- variety, MS- moisture stress level, V x MS- interaction between variety and moisture stress level, LSD, Least significant difference, $P$ - probability

(wet cotton wool and sand). In the first experiment, root dry weight was significantly affected by V x MS (Figure 4). However, all other root parameters were not significantly affected by the interaction of $\mathrm{V} \times \mathrm{MS}$. Taproot length at maturity was significantly different among the main effects of variety and moisture stress level. The highest taproot length was recorded in var. ANKCP2 and the lowest length was recorded in var. Dawala. However, taproot length of ANKCP2, MI35, Waruni, Wijaya and MICP1 were not significantly different from each other. Taproot length increased when increased moisture stress. It may be due to the expansion of taproot length to uptake more water under water-limited environments.
Matsui and Singh (2003) studied seedling root characteristics associated with drought tolerance found that drought tolerance of the variety IT96D-4 was related to root growth downwards by providing access to soil moisture in the deeper layers of the soil horizon under mild and severe water stress. Adu et al. (2019) suggested that large root systems with increased root biomass may not be beneficial all the time since the contribution of large roots systems on Carbon cost for plants is high. However, the investment of resources towards the growth and development of root systems of genotypes with long seasons would provide relative advantages at the later part of the growing season. Investing in root growth would be beneficial only if soil moisture is available at deeper layers of soil (high water storage capacity) as it requires high carbon cost. Water-saving strategies during initial growth stages would make water available for most critical stages sensitive to moisture such as the reproductive phase.

The basal root growth angle and taproot diameter at $5 \mathrm{~cm}$ from the soil, the surface were significantly different only among the main effect of moisture stress level. Lower moisture stress levels recorded the highest basal root growth angle and higher taproot diameter (Table 3). According to the results, it can be suggested that when increase the soil moisture stress plants tend to develop narrow growth angles of roots and deep root systems than high moisture levels in the soil. Furthermore, low root diameter at high soil moisture stress may be associated with the shrinkage of the root tissues (Faiz and Weatherley, 1982).

Seedling taproot length, total root length and seedling root dry weight were significantly affected by $\mathrm{V} \times \mathrm{MS}$ (Table 4) except the number of lateral roots per seedling in the second experiment. However, a number of lateral roots per seedling were significantly different $(\mathrm{P}<0.05)$ among main factors of variety and moisture stress level. Var. Dawala recorded the highest number of lateral roots while the lowest number of lateral roots was recorded in var. MI35. However, at higher 


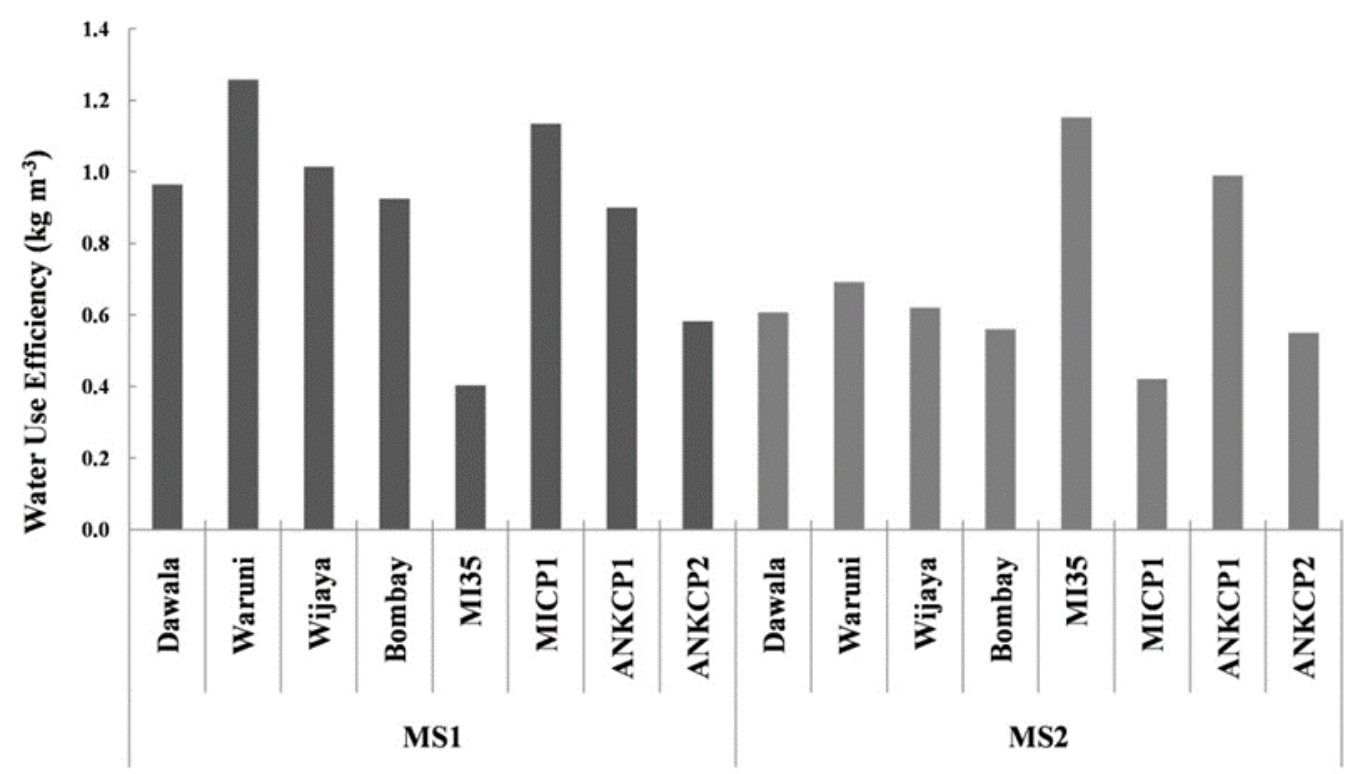

Figure 3: Effect of Variety $x$ Moisture stress level on water use efficiency $(\mathbf{P}<0.001 ;$ LSD $=0.35)$

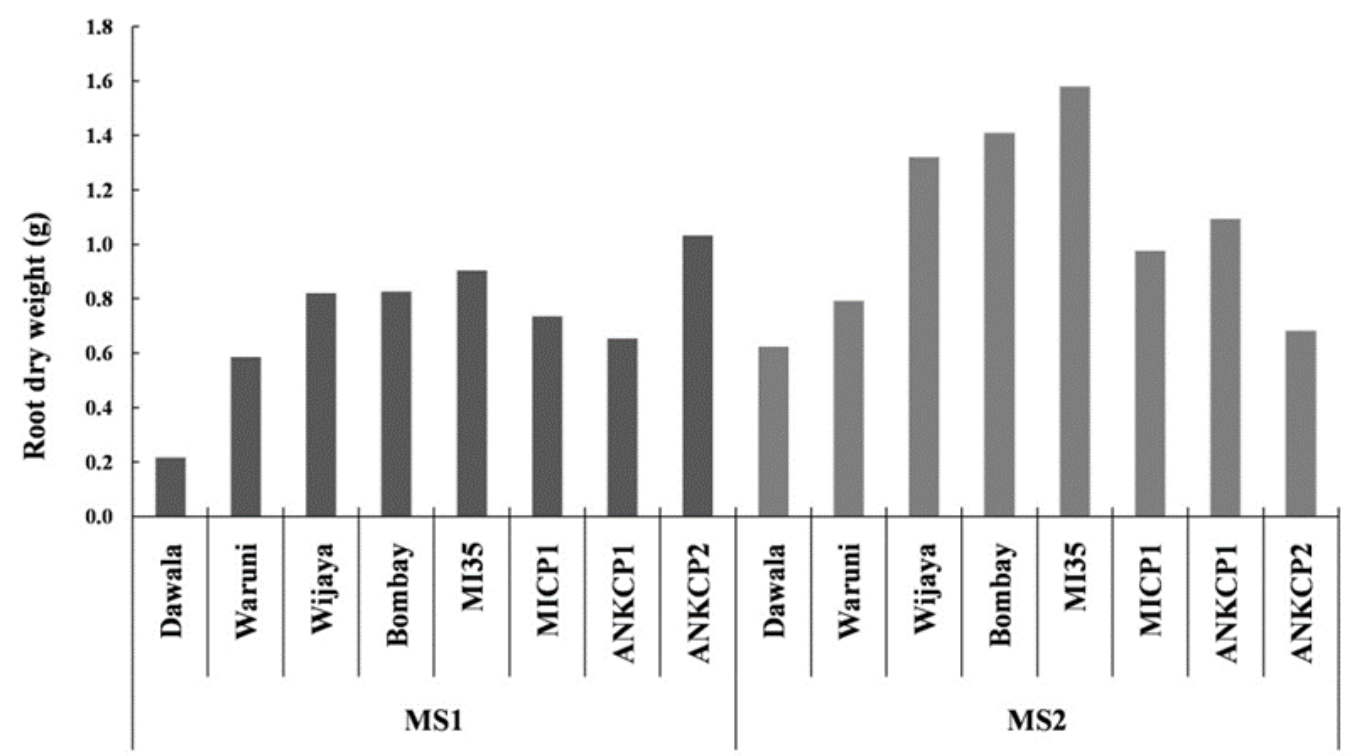

Figure 4: Effect of variety $x$ Moisture stress level on the dry weight of the roots at maturity $(\mathrm{P}<\mathbf{0 . 0 0 1}, \mathrm{LSD}=\mathbf{0 . 4 2})$

moisture stress levels plants produced higher number of lateral roots to uptake more moisture available in the growing media (Table 5).

In the third experiment, the interaction effect of $\mathrm{V} \times \mathrm{MS}$ was not significant for all measured parameters. The number of lateral roots and taproot length were significantly different $(\mathrm{P}<0.05)$ among main factors of variety and moisture stress level. Var. Dawala recorded the highest number of lateral roots and taproot length while the lowest number of lateral roots was recorded by var. MI35 and lowest taproot length was recorded var. ANKCP2. However, a higher moisture stress level was recorded a higher number of lateral roots and taproot length (Table 5) as in experiment 2. However, total root length, the number of lateral roots and the length of the taproot of all varieties were very high in sand media compared to cotton wool culture. This might be due to high space availability for the 
Table 3: Basal root growth angle, taproot diameter at $5 \mathrm{~cm}$ below the soil surface and length of the taproot with standard error of the means for eight cowpea varieties under two moisture stress levels at maturity.

\begin{tabular}{lccc}
\hline & \multicolumn{3}{c}{ Experiment 1 (at maturity) } \\
\cline { 2 - 4 } Treatments & $\begin{array}{l}\text { Basal root } \\
\text { growth angle } \\
\text { (degree) }\end{array}$ & $\begin{array}{l}\text { Taproot diameter } \\
\text { (cm) } \\
\text { (at 5 cm below } \\
\text { the soil surface) }\end{array}$ & $\begin{array}{l}\text { Length of } \\
\text { taproot (cm) }\end{array}$ \\
\hline Dawala & $60.50^{\mathrm{b}} \pm 4.03$ & $0.15^{\mathrm{a}} \pm 0.02$ & $15.33^{\mathrm{d}} \pm 1.22$ \\
Waruni & $62.33^{\mathrm{ab}} \pm 4.03$ & $0.17^{\mathrm{a}} \pm 0.04$ & $22.88^{\mathrm{ab}} \pm 1.51$ \\
Wijaya & $68.83^{\mathrm{ab}} \pm 3.78$ & $0.18^{\mathrm{a}} \pm 0.03$ & $21.83^{\mathrm{ab}} \pm 2.31$ \\
Bombay & $69.83^{\mathrm{ab}} \pm 4.25$ & $0.15^{\mathrm{a}} \pm 0.02$ & $20.75^{\mathrm{bc}} \pm 2.70$ \\
MI35 & $71.38^{\mathrm{a}} \pm 4.27$ & $0.14^{\mathrm{a}} \pm 0.02$ & $24.92^{\mathrm{a}} \pm 1.72$ \\
MICP 1 & $60.83^{\mathrm{b}} \pm 4.54$ & $0.16^{\mathrm{a}} \pm 0.02$ & $22.08^{\mathrm{ab}} \pm 1.85$ \\
ANKCP 1 & $66.70^{\mathrm{ab}} \pm 4.70$ & $0.17^{\mathrm{a}} \pm 0.03$ & $15.83^{\mathrm{cd}} \pm 1.33$ \\
ANKCP 2 & $68.33^{\mathrm{ab}} \pm 5.03$ & $0.13^{\mathrm{a}} \pm 0.01$ & $27.25^{\mathrm{a}} \pm 1.13$ \\
\hline P value (V) & 0.065 & 0.591 & $<\mathbf{0 . 0 0 1}$ \\
\hline MS1 & $58.10^{\mathrm{b}} \pm 1.70$ & $0.11^{\mathrm{b}} \pm 0.004$ & $22.63^{\mathrm{a}} \pm 1.21$ \\
MS2 & $74.01^{\mathrm{a}} \pm 1.32$ & $0.20^{\mathrm{a}} \pm 0.011$ & $20.10^{\mathrm{b}} \pm 1.03$ \\
\hline P value (MS) & $<\mathbf{0 . 0 0 1}$ & $<\mathbf{0 . 0 0 1}$ & $<\mathbf{0 . 0 5}$ \\
\hline
\end{tabular}

V- Variety, MS- moisture stress, LSD, Least significant difference, P- probability. Mean values followed by the same letters are not significantly different at $P<0.05$

growth of seedlings in glass boxes than in Petri dishes.

Onuh and Donald (2009) confirmed that in order to extract moisture from the atmosphere and retain water from the rhizosphere, cowpea plants growing in a water-stressed environment may begin to elongate their roots around the growth environment. As a result, the stem and roots become elongated and therefore longer than the average. Furthermore, according to the Santos et al. (2020), cowpea tends to prioritize root development overshoot development when subjected to severe drought stress, as indicated by substantial reductions in shoot dry weight, stem greenness, pod dry weight, number of pods per plant, and number of grains per plant, while root dry weight and root: shoot ratio significantly increased. Further, they confirmed drought tolerance screenings in cowpea take into account aboveground characteristics as well as root-related parameters.

Correlation between root traits and morphological parameters
Basal root growth angle and length of the taproot had a positive and moderate relationship with above-ground biomass at maturity. Furthermore, taproot length at $5 \mathrm{~cm}$ depth had a positive and week correlation with mature plant height. Length of the taproot, the number of lateral roots and total root length of seedlings under cotton wool media negatively and moderately correlated with above-ground biomass production at maturity. A negative and weak correlation was reported between the root dry weight and the above-ground biomass at maturity while the root dry weight of seedlings had a positive and moderate correlation with the plant height. There was a negative and moderate correlation between the total root length of the seedlings grown in sand media and the number of leaves per plant at maturity (Table $6)$.

\section{Correlation between root traits and yield parameters}

At maturity, the root dry weight of the plant showed a negative and moderate correlation with the number of flowers per plant and the number of pods per plant. In addition to that 
Table 4: Interaction effect between variety and moisture stress level on taproot length, total root length and dry weight of the seedlings raised in the cotton wool culture at seven days after seed sowing.

\begin{tabular}{|c|c|c|c|c|}
\hline \multirow{2}{*}{$\begin{array}{c} \\
\text { Treatment } \\
\text { (Moisture } \\
\text { stress level) }\end{array}$} & \multirow[b]{2}{*}{$\begin{array}{l}\text { Treatment } \\
\text { (Variety) }\end{array}$} & \multicolumn{3}{|c|}{$\begin{array}{c}\text { Experiment } 2 \\
\text { (Seedlings in cotton wool culture) }\end{array}$} \\
\hline & & $\begin{array}{l}\text { Length of } \\
\text { taproot } \\
\text { (cm) }\end{array}$ & $\begin{array}{c}\text { Total root } \\
\text { length } \\
\text { (cm) }\end{array}$ & $\begin{array}{c}\text { Root dry } \\
\text { weight } \\
\text { (g) } \\
\end{array}$ \\
\hline \multirow{8}{*}{ MS1 } & Dawala & 4.05 & 8.33 & 0.95 \\
\hline & Waruni & 3.35 & 6.76 & 0.70 \\
\hline & Wijaya & 3.40 & 7.34 & 0.89 \\
\hline & Bombay & 3.61 & 7.79 & 0.84 \\
\hline & MI35 & 3.27 & 5.81 & 0.27 \\
\hline & MICP1 & 3.21 & 5.80 & 0.69 \\
\hline & ANKCP1 & 3.30 & 6.56 & 1.33 \\
\hline & ANKCP2 & 2.94 & 5.47 & 0.57 \\
\hline \multirow{9}{*}{ MS2 } & Dawala & 3.65 & 8.09 & 1.01 \\
\hline & Waruni & 3.64 & 7.61 & 0.77 \\
\hline & Wijaya & 3.76 & 7.74 & 0.90 \\
\hline & Bombay & 3.75 & 8.13 & 1.46 \\
\hline & MI35 & 3.48 & 6.00 & 0.42 \\
\hline & MICP1 & 3.70 & 6.20 & 1.03 \\
\hline & ANKCP1 & 3.63 & 7.38 & 1.34 \\
\hline & ANKCP2 & 3.84 & 8.15 & 0.63 \\
\hline & $\overline{\mathbf{V} \times \mathbf{M S}_{[\mathrm{LSD}]}}$ & 0.406 & 1.126 & 0.004 \\
\hline P value & & $<0.01$ & $<0.05$ & $<0.001$ \\
\hline
\end{tabular}

V- variety, MS- moisture stress level, LSD, Least significant difference, $\mathrm{P}$ probability

basal root growth angle had a positive and weak relationship with the number of pods per plant while the positive and moderate correlation with, the number of seeds per pod, the pod length and 100 seed dry weight. Taproot diameter at $5 \mathrm{~cm}$ level had a positive and moderate relationship with the number of flowers per plant, number of pods per plant, number of seeds per pod, the pod length and 100 seed dry weight. There was a positive and moderate correlation found between the total root length and the number of flowers per plant.

A negative and moderate correlation between root dry weight of the seedlings grown in cotton media with the number of seeds per pod. The length of the taproot of the seedlings raised in sand media had a negative and moderate relationship with the number of pods per plant and the number of seeds per plant. Furthermore, the number of lateral roots per plant of the same experiment had a negative and moderate correlation with the number of seeds per pod of the mature plant (Table 7). According to Alidu (2018), pods per plant, root weight, shoot weight and seeds per pod were positively correlated with grain weight while root weight was positively correlated with shoot weight.

\section{CONCLUSION}

The interaction between variety and moisture stress on all morphological traits and some of the yield and root attributes was not significant in the present study. However, the variation among variety and moisture stress 
Table 5: Effect of variety and moisture stress level on the number of lateral roots in the second and third experiment, length of taproot and total root length of the third experiment where seedlings raised in sand media at seven days after seed sowing with standard error of the means.

\begin{tabular}{|c|c|c|c|c|}
\hline \multirow{2}{*}{ Treatments } & \multirow{2}{*}{$\begin{array}{l}\text { Experiment } 2 \\
\text { ( Seedlings in } \\
\text { cotton wool } \\
\text { culture) } \\
\text { Number of } \\
\text { lateral roots }\end{array}$} & \multicolumn{3}{|c|}{ Experiment 03 (Seedlings in sand media) } \\
\hline & & $\begin{array}{l}\text { Length of } \\
\text { Taproot }\end{array}$ & $\begin{array}{l}\text { Number of lateral } \\
\text { roots }\end{array}$ & Total root length \\
\hline Dawala & $32.09^{\mathrm{a}} \pm 2.66$ & $24.34^{\mathrm{a}} \pm 1.15$ & $69.56^{\mathrm{a}} \pm 6.41$ & $124.22^{\mathrm{a}} \pm 12.19$ \\
\hline Waruni & $20.38^{\mathrm{cd}} \pm 1.58$ & $17.04^{\mathrm{bc}} \pm 1.29$ & $37.29^{\mathrm{bc}} \pm 2.27$ & $54.44^{\mathrm{de}} \pm 2.20$ \\
\hline Wijaya & $20.37^{\mathrm{cd}} \pm 1.55$ & $23.05^{\mathrm{ab}} \pm 1.58$ & $42.19^{\mathrm{bc}} \pm 5.84$ & $79.39^{\mathrm{bcd}} \pm 7.18$ \\
\hline Bombay & $28.15^{\mathrm{ab}} \pm 2.59$ & $21.21^{\mathrm{abc}} \pm 1.25$ & $65.37^{\mathrm{a}} \pm 5.16$ & $105.80^{\mathrm{ab}} \pm 6.00$ \\
\hline MI35 & $16.41^{\mathrm{d}} \pm 1.35$ & $18.73^{\mathrm{abc}} \pm 1.62$ & $31.14^{c} \pm 6.23$ & $63.01^{\text {cde }} \pm 8.03$ \\
\hline MICP 1 & $20.11^{\mathrm{cd}} \pm 0.88$ & $16.77^{\mathrm{bc}} \pm 2.14$ & $31.43^{c} \pm 7.26$ & $45.59^{\mathrm{e}} \pm 7.59$ \\
\hline ANKCP 1 & $23.18^{b c} \pm 1.51$ & $21.50^{\mathrm{abc}} \pm 1.34$ & $61.55^{\mathrm{a}} \pm 7.59$ & $74.82^{\text {cd }} \pm 5.45$ \\
\hline ANKCP 2 & $21.43^{\mathrm{c}} \pm 2.97$ & $15.85^{\mathrm{c}} \pm 1.41$ & $50.46^{\mathrm{ab}} \pm 5.85$ & $80.79^{\mathrm{bc}} \pm 10.06$ \\
\hline P value (V) & $<0.001$ & 0.022 & $<0.001$ & $<0.001$ \\
\hline MS1 & $24.63^{\mathrm{a}} \pm 1.07$ & $22.87^{\mathrm{a}} \pm 0.76$ & $54.29^{\mathrm{a}} \pm 3.48$ & $81.86^{\mathrm{a}} \pm 5.66$ \\
\hline MS2 & $20.60^{b} \pm 1.26$ & $16.76^{b} \pm 0.85$ & $41.26^{b} \pm 3.22$ & $71.67^{\mathrm{a}} \pm 5.25$ \\
\hline P value (MS) & $<0.001$ & $<0.001$ & $<0.01$ & 0.1074 \\
\hline
\end{tabular}

V- variety, MS- moisture stress level, $P$ - probability Mean values followed by the same letters are not significantly different at $P<0.05$

Table 6: Correlation coefficient between root traits and morphological traits of cowpea

\begin{tabular}{|c|c|c|c|c|c|}
\hline $\begin{array}{l}\text { Growth stage } \\
\text { of the plant }\end{array}$ & Parameters & $\begin{array}{c}\text { Number of } \\
\text { branches }\end{array}$ & $\begin{array}{c}\text { Plant } \\
\text { height }\end{array}$ & $\begin{array}{c}\text { Number of } \\
\text { leaves }\end{array}$ & $\begin{array}{c}\text { Above ground } \\
\text { biomass }\end{array}$ \\
\hline \multirow{4}{*}{ At maturity } & RDW & $0.091^{\mathrm{ns}}$ & $-0.051^{\mathrm{ns}}$ & $0.074^{\mathrm{ns}}$ & $0.037^{\mathrm{ns}}$ \\
\hline & BRGA & $-0.018^{\mathrm{ns}}$ & $0.184^{\mathrm{ns}}$ & $0.025^{\mathrm{ns}}$ & $0.439^{* *}$ \\
\hline & TRD5 & $0.161^{\mathrm{ns}}$ & $0.289^{*}$ & $0.233^{\mathrm{ns}}$ & $0.255^{\text {ns }}$ \\
\hline & LTR & $-0.197^{\mathrm{ns}}$ & $-0.131^{\mathrm{ns}}$ & $-0.145^{\mathrm{ns}}$ & $0.371^{* *}$ \\
\hline \multirow{4}{*}{$\begin{array}{l}\text { Seedlings } \\
\text { (cotton wool) }\end{array}$} & LTR & $-0.078^{\mathrm{ns}}$ & $0.059^{\mathrm{ns}}$ & $-0.113^{\mathrm{ns}}$ & $-0.305^{\prime \prime}$ \\
\hline & NLR & $-0.093^{\mathrm{ns}}$ & $0.148^{\mathrm{ns}}$ & $-0.196^{\mathrm{ns}}$ & $-0.316^{*}$ \\
\hline & TRL & $-0.102^{\mathrm{ns}}$ & $0.210^{\mathrm{ns}}$ & $-0.216^{\mathrm{ns}}$ & $-0.316^{*}$ \\
\hline & RDW & $0.092^{\mathrm{ns}}$ & $0.322^{*}$ & $-0.194^{\mathrm{ns}}$ & $-0.285^{*}$ \\
\hline \multirow{3}{*}{$\begin{array}{l}\text { Seedlings } \\
\text { (sand media) }\end{array}$} & LTR & $0.203^{\mathrm{ns}}$ & $-0.044^{\mathrm{ns}}$ & $0.155^{\mathrm{ns}}$ & $-0.275^{\mathrm{ns}}$ \\
\hline & NLR & $0.221^{\mathrm{ns}}$ & $0.052^{\mathrm{ns}}$ & $-0.117^{\mathrm{ns}}$ & $-0.157^{\mathrm{ns}}$ \\
\hline & TRL & $-0.063^{\mathrm{ns}}$ & $-0.011^{\mathrm{ns}}$ & $-0.340^{*}$ & $-0.250^{\mathrm{ns}}$ \\
\hline
\end{tabular}

Remarks: RDW=Root Dry Weight, BRGA=Basal Root Growth Angle, TRD5=Taproot Diameter at 5cm level, LTR=Length of Taproot, NLR=Number of Lateral Roots, TRL=Total Root Length, ${ }^{* * *}=$ significant at $\mathbf{P}<0.001,{ }^{* *}=$ significant at $\mathbf{P}<0.01,{ }^{*}=$ significant at $\mathbf{P}<0.05$, ns $=$ not significant.

levels for those traits was significantly different. Moderate to weak relationships found between root attributes with morphological and yield characteristics of cowpea. Basal root growth angle and total root length had a positive relationship with above-ground biomass production at maturity. The root traits include the length of the taproot, number of lateral roots, total root length and root dry weight of seedling in the cotton wool culture associated negatively with above-ground biomass production at maturity. 
Table7:Correlation coefficient between root traits and yield traits of cowpea

\begin{tabular}{|c|c|c|c|c|c|c|}
\hline $\begin{array}{l}\text { Growth stage } \\
\text { of the plant }\end{array}$ & Parameters & $\begin{array}{l}\text { Number of } \\
\text { flowers/plant }\end{array}$ & $\begin{array}{c}\text { Number } \\
\text { of pods/ } \\
\text { plant }\end{array}$ & $\begin{array}{c}\text { Number } \\
\text { of seeds/ } \\
\text { pod }\end{array}$ & $\begin{array}{c}\text { Average } \\
\text { pod } \\
\text { length }\end{array}$ & $\begin{array}{c}100 \\
\text { seeds } \\
\text { dry } \\
\text { weight }\end{array}$ \\
\hline \multirow{4}{*}{ At maturity } & RDW & $-0.483^{2 \pi \%}$ & $-0.464^{* * \pi}$ & $-0.162^{\mathrm{ns}}$ & $-0.230^{\mathrm{ns}}$ & $-0.140^{\mathrm{ns}}$ \\
\hline & BRGA & $0.076^{\mathrm{ns}}$ & $0.299^{*}$ & $0.592^{* * * *}$ & $0.617^{* * *}$ & $0.494^{* *}$ \\
\hline & TRD5 & $0.473^{* *}$ & $0.567^{* * *}$ & $0.441^{* *}$ & $0.335^{*}$ & $0.319^{*}$ \\
\hline & TRL & $-0.429^{* *}$ & $-0.179^{\mathrm{ns}}$ & $0.622^{\mathrm{ns}}$ & $0.017^{\mathrm{ns}}$ & $-0.191^{\mathrm{ns}}$ \\
\hline \multirow{4}{*}{$\begin{array}{c}\text { Seedlings } \\
\text { (wet cotton } \\
\text { wool) }\end{array}$} & LTR & $0.099^{\mathrm{ns}}$ & $-0.182^{\mathrm{ns}}$ & $-0.154^{\mathrm{ns}}$ & $-0.109^{\mathrm{ns}}$ & $-0.144^{\mathrm{ns}}$ \\
\hline & NLR & $0.061^{\mathrm{ns}}$ & $-0.159^{\mathrm{ns}}$ & $-0.193^{\mathrm{ns}}$ & $-0.144^{\mathrm{ns}}$ & $0.040^{\mathrm{ns}}$ \\
\hline & TRL & $0.083^{\text {ns }}$ & $-0.108^{\mathrm{ns}}$ & $-0.219^{\mathrm{ns}}$ & $-0.147^{\mathrm{ns}}$ & $-0.014^{\mathrm{ns}}$ \\
\hline & RDW & $0.071^{\mathrm{ns}}$ & $-0.171^{\mathrm{ns}}$ & $-0.479^{* * *}$ & $-0.202^{\mathrm{ns}}$ & $0.271^{\mathrm{ns}}$ \\
\hline \multirow{3}{*}{$\begin{array}{c}\text { Seedlings } \\
\text { (sand media) }\end{array}$} & LTR & $-0.225^{\mathrm{ns}}$ & $-0.312^{\pi}$ & $-0.347^{\pi}$ & $-0.301^{\mathrm{ns}}$ & $-0.179^{\mathrm{ns}}$ \\
\hline & NLR & $-0.168^{\mathrm{ns}}$ & $-0.260^{\mathrm{ns}}$ & $-0.327^{*}$ & $-0.258^{\mathrm{ns}}$ & $0.115^{\mathrm{ns}}$ \\
\hline & TRL & $-0.086^{\mathrm{ns}}$ & $-0.223^{\mathrm{ns}}$ & $-0.207^{\mathrm{ns}}$ & $-0.060^{\mathrm{ns}}$ & $0.235^{\mathrm{ns}}$ \\
\hline
\end{tabular}

Remarks: RDW=Root Dry Weight, BRGA=Basal Root Growth Angle, TRD5=Taproot Diameter at 5cm level, $L T R=$ Length of Taproot, NLR=Number of Lateral Roots, TRL=Total Root Length, ${ }^{* * *}=$ significant at $\mathbf{P}<0.001,{ }^{* *}=$ significant at $\mathbf{P}<0.01, \stackrel{*}{=}$ significant at $\mathbf{P}<0.05$, ns $=$ not significant

However, only the total root length of the seedlings in sand media reported a negative relationship with the number of leaves per pant as a morphological trait. Furthermore, basal root growth angle and taproot diameter at $5 \mathrm{~cm}$ below the soil surface of mature plant identified as favourable root traits which could enhance the production of the number of pods per plant, the number of seeds per pod, pod length and 100 seeds weight of cowpea at maturity under moisture stress conditions. Moreover, the taproot length of the seedlings of sand media had a negative relationship with the number of pods per plant and the number of seeds per pod while the number of lateral roots showed a negative association with the number of seeds per pod. Identified favourable root attributes related to morphology and yield components of cowpea could be used as screening parameters of cowpea populations at the seedling stage to find out efficient genotypes under soil moisture stress levels and introduce them to breeding programs.

\section{AUTHOR CONTRIBUTION}

HKAH performed the experiments, analysed \& interpreted data. KMCF conceptualised \& designed the study. HKAH and KMCF contributed in drafting the manuscript. $\mathrm{KMCF}$ critically revised the manuscript

\section{References}

Abayomi YA and Abidoye TO 2009 Evaluation of cowpea genotypes for soil moisture stress tolerance under screen house conditions. African Journal of Plant Science, 3(10): 229237.

Abearathne MS, Hettiarachchi K, Chithrapala NHMS and Samarakoonmanike SM 2013 MICP 01- A New cowpea [vigna unguiculata (L.) Walp.] variety for cultivation in dry and intermediate zones of Sri Lanka. Annals of Sri Lanka Department of Agriculture, 15: 100-108.

Adu MO, Asare PA, Yawson DO, Dzidzienyo DK, Nyadanu D, Asare-Bediako E, Afutu E, Tachie-Menson JW and Amoah MN 2019 Identifying key contributing root system traits to genetic diversity in field-growncowpea (Vigna unguiculata L. Walp.) genotypes. Field Crops Research, 232: 106-118. https://doi.org/10.1016/ j.fcr.2018.12.015

Agbicodo EM, Fatokun CA, Muranaka S, Visser RGF and Linden Van Der CG 2009 Breeding drought tolerant cowpea: constraints, accomplishments, and future prospects. Euphytica, 167: 
353-370. https://doi.org/10.1007/ s10681-009-9893-8.

AgStat 2020 Agricultural Statistics, SocioEconomic and Planning Centre, Department of Agriculture, Peradeniya, Sri Lanka, Volume XVII

Alidu MS 2018 Evaluation of Cowpea Genotypes for Drought Tolerance Using the Pot Screening Approach. Asian Research Journal of Agriculture,10(2): 1-11. 10.9734/ ARJA/2018/45806

Burridge J, Jochua CN, Bucksch A and Lynch JP 2016 Legume shovelomics: HighThroughput phenotyping of common bean (Phaseolus vulgaris L.) and cowpea (Vigna unguiculata subsp, unguiculata) root architecture in the field. Field Crops Research, 192:2132. doi:10.1016/j.fcr.2016.04.008

Carlos G 2000 Cowpea: Post Harvest Operation. Food and Agricultural Organization ofUnited Nations, Rome, Italy.

Carvalho M, Castro I, Moutinho-Pereira J, Correia C, Egea-Cortines M, Matos M, Rosa E, Carnide V and Lino-Neto T 2019 Evaluating stress responses in cowpea under drought stress. Journal of Plant Physiology: 153001. https:// doi.org/10.1016/j.jplph.2019.153001

Cruz de Carvalho MH 2008 Drought stress and reactive oxygen species: production,scavenging and signalling. Plant Signaling \& Behavior, 3(3): 156 -165 . psb.3.3.5536.

Faiz SMA and Weatherley PE 1982 Root contraction in transpiring plants. New Phytologist, 92(3): 333-343. https:// doi.org/10.1111/j.1469-

8137.1982.tb03391.x

Farooq M, Wahid A, Kobayashi N, Fujita D and Basra SMA 2009 Plant Drought Stress: Effects, Mechanisms and Management. In E Lichtfouse, M Navarrete, P Debaeke, S Véronique and C Alberola (eds), Sustainable Agriculture, Springer, Dordrecht, pp. 153-188. https://doi.org/10.1007/97890-481-2666-8 12
Hatfield JL, Boote KJ, Kimball BA, Ziska $\mathrm{LH}$, Izaurralde RC, Ort D, Thomson $\mathrm{AM}$ and Wolfe D 2011 Climate Impacts on Agriculture: Implications for Crop Production. Agronomy Journal, 103(2): 351-370. https:// doi.org/10.2134/agronj2010.0303

Lesk C, Rowhani P and Ramankutty N 2016 Influence of extremeweather disasters on global crop production. Nature, 529: 84-87. https://doi.org/10.1038/ nature 16467

LynchJP 2013 Steep, cheap and deep: an ideotype to optimize water and $\mathrm{N}$ acquisition by maize root systems. Annals of Botany,112: 347-357, http://dx.doi.org/10.1093/aob/mcs293

Lynch J and van Beem JJ 1993 Growth and Architecture of Seedling Roots of Common Bean Genotypes. Crop Science, 33(6): 1253-1257.https:// doi.org/10.2135/ cropsci1993.0011183X003300060028 $\mathrm{x}$

Martins LM, Xavier GR, Rangel FW, Ribeiro JR, Nevesm MC, Morgado LB and Rumjanek NG 2003 Contribution of biological nitrogen fixation to cowpea: astrategy for improving grain yield in the semi-arid region of Brazil. Biology and Fertility Soils, 38: 333339.https://doi.org/10.1007/s00374003-0668-4

Matsui $\mathrm{T}$ and Singh BB 2003 Root characteristics in cowpea related to drought tolerance at the seedling stage. Experimental Agriculture, 39(1): 2938.doi:10.1017/s0014479703001108

Merwad AMA, Desoky EM and Rady MM 2018Response of water deficitstressed Vigna unguiculata performances to silicon, proline or methionine foliar application. Scientia Horticulturae, 26: 132-144. https:// doi.org/10.1016/j.scienta.2017.10.008

Mwale SE, Ochwo-Ssemakula M, Sadik K, Achola E, Okul V, Gibson P, Edema R, Singini W and Rubaihayo P 2017 Response of Cowpea Genotypes to Drought Stress in Uganda. American Journal of Plant Sciences, 8(4): 720733.10.4236/ajps.2017.84050 
Ndimbo MA, Nchimbi-Msolla S and Semu E 2015 Effects of moisture stress levels at different growth stages on nodulation and nitrogen fixation in common bean (Phaseolus vulgaris L .) Genotype. Asian Journal of Agriculture and Rural Development, 5 (8): 187-201.DOI: $\quad 10.18488 /$ journal.1005/2015.5.8/1005.8.187.20

Onuh M and Donald K 2009 Effects of water stress on the rooting, nodulation potentials and growth of cowpea (Vigna unguiculata (L) Walp). Science World Journal, 4(3): 31-34. 10.4314/swj.v4i3.51858

Santos R, Carvalho M, Rosa E, Carnide V and Castro I 2020 Root and AgroMorphological Traits Performance in Cowpea under Drought Stress. Agronomy, 10(10):1604; https:// doi.org/10.3390/agronomy10101604

Schonfeld MA, Johnson RC, Carver BF and Mornhinweg DW 1988 Water Relations in Winter Wheat as Drought Resistance Indicators. Crop Science, 28 (3): 526-531. https:// doi.org/10.2135/ cropsci1988.0011183X002800030021 $\mathrm{X}$

Singh B 2014 Cowpea: The Food Legume of the 21 stCentury. Madison, WI, USA: Crop Science Society of America.

Tejero I G, Zuazo VHD, Bocanegra JAJ and Fernández JLM 2011 Improved wateruse efficiency by deficit-irrigation programmes: Implications for saving water in citrus orchards. Scientia Horticulturae, $128 \quad$ (3): 274 282.https://doi.org/10.1016/ j.scienta.2011.01.035

Timko MP, Ehlers JD and Roberts PA 2007 Cowpea. In: Kole, C. (Ed.), Genome Mapping and Molecular Breeding in Plants: Pulses, Sugar and Tuber Crops. SpringerVerlag, Berlin, pp. 49 $-67$.

Yahaya D, Denwar N and Blair MW 2019 Effects of Moisture Deficit on the Yield of Cowpea Genotypes in the Guinea Savannah of Northern Ghana. Agricultural Sciences, 10(4): $577-$ 595. 